Edy t a M. Nieduziak

ORCID: 0000-0002-7072-4448

University of Silesia in Katowice

\section{Family Art Therapy: Towards Possible Applications of an Underestimated Form of Art Therapy}

Arteterapia rodzinna. Ku możliwym zastosowaniom niedocenianej formy arteterapii

\begin{abstract}
The main purpose of the article is to present various ways of conducting art therapy with families, which is often referred to as Family Art Therapy. In the first part, the author explains the sources and unique features of this form of work, before proceeding to characterize therapeutic interventions described in the literature on the subject. Although they are not numerous, they present a wide range of possibilities for the use of Family Art Therapy. The author, therefore, proposes a division into three main groups of problems: (1) the functioning of the family is disturbed as a result of the health condition of one of its members; most often it is a child who is experiencing severe mental disorders, e.g. schizophrenia, mood disorders, depression, suicide attempts, etc. or ADHD, ASD and neurodevelopmental disorders; (2) the functioning of the family is disturbed as a result of external conditions: a crisis situation, or domestic violence; (3) disturbances in the relationship between the parent(s) and the child. These various family problems require different techniques and exercises, which has been highlighted in the characteristics of the different ways of working with families.
\end{abstract}

KEYWORDS

art therapy, art therapy and family therapy, Family Art Therapy, Hanna Kwiatkowska, schizophrenia, ADHD, ASD, crisis situations, domestic violence, parentchild relationships, responsive art therapy, genogram

StOWA KLUCZOWE

arteterapia, arteterapia i terapia rodzinna, Family Art Therapy, Hanna Kwiatkowska, schizofrenia, ADHD, ASD, sytuacje kryzysowe, przemoc domowa, relacje rodzic-dziecko, arteterapia responsywna, genogram

SPI Vol. 24, 2021/4 ISSN 2450-5358 e-ISSN 2450-5366 DOI: 10.12775/SPI.2021.4.008

Submitted: 1.08 .2021 Accepted: 18.11.2021

Articles and dissertations 
The article is also complemented by short descriptions of art-therapy works prepared by art therapy students, the starting point for which was the use of a diagnostic and therapeutic genogram technique for creative, artistic work and self-reflection on one's own family.

The article ends with the significant words of the precursor of Family Art Therapy, Hanna Kwiatkowska showing the value of this form of work not only for its participants but also for art therapists.

\section{ABSTRAKT}

Głównym celem artykułu jest prezentacja różnych sposobów pracy arteterapeutycznej z rodzinq, co często jest określane mianem Family Art Therapy. W pierwszej części autorka wyjaśnia źródła oraz specyfikę tej formy pracy, po czym przechodzi do charakterystyki dostępnych w literaturze przedmiotu opisów interwencji terapeutycznych. Choć nie sq one liczne, prezentuja jednak szeroki wachlarz możliwości zastosowania Family Art Therapy. Autorka proponuje podział na trzy zasadnicze grupy problemów podejmowanych w interwencjach: (1) funkcjonowania rodziny, zaburzonego w wyniku stanu zdrowia któregoś z członków; najczęściej jest to dziecko, kłóre doświadcza ciężkich zaburzeń psychicznych, np. schizofrenii, zaburzeń nastroju - depresji, próby samobójczej itp. albo zaburzeń neurorozwojowych ADHD, ASD; (2) funkcjonowania rodziny, zaburzonego w wyniku uwarunkowań zewnętrznych: sytuacji kryzysowej, przemocy domowej; (3) zaburzeń relacji rodzic-dziecko, ewentualnie rodzice-dziecko.

Te różne problemy rodzinne wymagaja zastosowania innych technik i ćwiczeń co zostało uwypuklone w charakterystyce poszczególnych sposobów pracy z rodzinami.

Artykuł uzupełniają także krótkie opisy prac arteteraputycznych przygotowanych przez studentów kierunku arteterapia, dla kłórych punktem wyjścia było wykorzystanie techniki diagnostycznej i terapeutycznej genogramu do pracy twórczej, artystycznej oraz autorefleksji nad własnq rodzinq.

Całość kończq znamienne słowa prekursorki Family Art Therapy Hanny Kwiatkowskiej ukazujq̨cej wartości tej formy pracy nie tylko dla jej uczestników, ale także dla arteterapeutów. 


\section{Introduction}

Much has been written about the importance of the family in the life of every human being. We know about its beneficial influence on the development of children and the considerable development potential provided by optimal family life conditions. Therefore, for many people, the family is a value in itself (Frąckowiak 2007; Swadźba 2012; Dziewięcka-Bokun 2010). In consequence, any symptoms of disturbances in its functioning, such as family breakdown, Euro-orphanhood, an increase in the number of children using institutionalized forms of foster care, and a decrease in the number of adoptions and foster families are worrying. These phenomena become a stimulus to create various forms of help and support for the families, including family therapies based on all theoretical concepts. According to Marian Bybluk (2009), psychological assistance to families is not sufficiently widespread and appreciated in Poland. Meanwhile, in many Western European countries and the USA, it is one of the most commonly used forms of assistance. Among the American pioneers of family therapy, Jay Haley, Milton H. Erickson, Salvador Minuchin, Humberto Maturan, and Virginia Satir, listed by the aforementioned author, only V. Satir (cf. 2000a; 2000b) and M.H. Erickson (1997) are commonly known in Poland. Thanks to the latter, J. Haley (1995) is also known, but not as the author of his own publications, but as the author of books about M.H. Erickson, with whom he also collaborated. Only psychotherapists who are more interested in the practice and who specialize in working with families read the classics (Minuchin 2018), or for the continuators of their thoughts and practices, or, on the contrary, for their opponents. Today, we can distinguish numerous approaches in family therapy, from the frequently used systemic approach (Chrząstowski 2014; Górniak, Józefik 2003) and behavioral approach (Kuźnik, Landwójtowicz 2019), through psychoanalysis (Emanuel, Bradley 2018), (Dattilio 2013), positive therapy (Peseschkian 2015), acceptance and commitment therapy (Coyne, Murrell 2020), IFS therapy (Anderson, Sweezy, Schwartz 2020) to the controversial system settings of Bert Hellinger (Hellinger, Hovel 2003) or feminist approaches (Braverman 2003). 
The above-mentioned wide range of approaches in working with families does not exhaust the therapeutic possibilities which are also conditioned by the qualifications of the therapists themselves. Pedagogues, sociotherapists and special educators work differently, focused on different aspects of family functioning. However, this diversity shows the rich context of therapeutic phenomena against which the Family Art Therapy ranks "as a natural consequence of the development of the theory of family therapies" (Malchiodi 2014: 474). This is confirmed by the words of Hanna Y. Kwiatkowska (1967), considered a precursor of Family Art Therapy. In the 1960s, she noticed a growing interest in psychiatric research in the role of the family in the etiology of some mental disorders, and at the same time she emphasized the increasingly well-established position of art therapy techniques in the work of psychiatrists. The combination of the skills of art therapists and the knowledge of psychiatrists about the relationships and links between the functioning of the family and the mental problems of patients, especially those suffering from schizophrenia, created circumstances that led to the emergence of a specific group of psychotherapeutic techniques. Referring to my experience at the National Institute of Mental Health, I point here to the pioneering nature of Family Art Therapy, which consisted in enriching individual work with the patient by introducing the participation of family members into the therapeutic program, initially during visits, and finally by making it an integral part of the program. The aim of the article is to present the idea and practice of Family Art Therapy along with possible art therapy interventions in group and individual work.

\section{What is Family Art Therapy?}

Family Art Therapy is a form of psychotherapeutic work, in which art therapy techniques are used to solve a problem affecting a given family. These two basic features define its essence, which does not consist of any preferred psychological concept of a person, nor of a chosen school of family therapy, nor of a choice of specific forms of artistic expression. Family Art Therapy uses various artistic media, both visual and derived from other artistic disciplines, e.g. writing, storytelling, dance, movement, play, music, drama, theater, and draws 
on various psychotherapeutic trends, including classical psychoanalysis, object relations theory and attachment theory (Parashak 2008), through the structural approach (Hoshino 2008), the empirical approach(Kerr 2008b), references to Alfred Adler's concept (Sutherland 2008, 2011), Carl Rogers (McCarley 2008), Murray Bowen (Kerr 2008a), to narrative therapies (Hoshino, Cameron 2008) and other approaches, e.g. the phenomenological approach (Plante, Bernèche 2008).

The fact that Kwiatkowska treated Family Art Therapy as a psychotherapeutic technique resulted from its narrow application in the psychiatric practice of people and families experiencing schizophrenia as well as its reliance on the principles of psychodynamic therapies. Over time, however, the application of this technique has significantly expanded, as evidenced by the embedding of art therapy practices with families in heterogeneous theoretical approaches, in cooperation with various schools of family therapy and using heterogeneous forms of expression. Therefore, the term is currently used to describe forms of therapy that combine art therapy and family therapy (Manicom, Boronska 2003, Sumari 2005, Kerr, Hoshino, Sutherland, Parashak, and McCarley 2008).

The most frequently cited property of Family Art Therapy is the use of art as a means of communication, and thus a change in the way of communication from language to art media, which allows for freer self-expression in the family. This form simultaneously engages all family members in expressive activities, which is not possible with the use of psychotherapy based only on verbal statements. "Art therapy provides family with an effective and unique treatment option offering a distinctive, balance process. Since art transcends language, it spans the cultural, language and age barriers that influence family power and balance. Engaging the family through art levels the playing field, providing a new venue for each family member to communicate equally" (Hoshino 2016: 211). Moreover, as a form of art therapy, it is implemented in less formal situations with the use of indirect means of communication (Kwiatkowska 1967), that is, with the use of art.

Depending on the problem to be solved, as well as the tenets preferred by therapists, emphasis is placed on various elements in such communication. For example, while creating a therapy program for 
families in crisis, Hilary Manicom, family therapist (Senior Social Worker/Family Therapist) and Teresa Boronska, art therapist (Senior Art Therapist) tapped into the potential of spontaneous family creativity (Manicom, Boronska 2003). The symbolic nature of non-verbal communication, in their opinion, makes it possible to reveal the thoughts and feelings that arise during therapy in an alternative way. Let us recall here that many years before, Kwiatkowska $(1967,1978)$ saw the main task of therapy in the understanding of the symbolism contained in the works of the participants of the process. They focused on family stories whose discovery could help shed light on the problem.

"These stories might well relate to problems which brought the family to therapy in the first place, or focus on the strengths that the family might have forgotten in their crisis. In using alternative means of communication, families can begin to engage in a different way, adding an element of surprise to a potentially difficult endeavor" (Manicom, Boronska 2003: 217). The narrative structure of Family Art Therapy is also highlighted by Malchiody (2014), who shows the importance of not only recreating stories but also inventing their feel-good continuation.

The author, referring to her own previous publications (Riley, Malchiodi 2004) and those of other art therapists (Riley 1988 1991; Selekman 2010), defines Family Art Therapy as a method of work with a high diagnostic potential, based on the assumption that "artworks created together or individually by a couple or family members can be viewed as a visual representation of interpersonal dynamics and the family system" (Malchiodi 2014: 475). Thus, she emphasizes the evaluative function of this form of therapy.

One of the more recent approaches in Family Art Therapy is to focus on emotional exchanges between family members. It continues the theme of non-verbal communication in the family circle and the possibility of creating a dialogical exchange. The task of responsive family art psychotherapy is to uncover emotions that are damaging family relationships, e.g. anxiety, transferred from generation to generation, which prevents open, trusting communication, especially in moments of crisis. It focuses on creating qualitatively new relationships rather than on searching for the causes of disorders. It is one of those approaches in which it is important to work in caregiver-child 
pairs, and not only with the whole family (Nielsen, Feijo, Renshall, Starling 2021).

On the other hand, Family Art Therapy provides an opportunity for researchers of family relations to observe the functioning of the family, its dynamics and transactional patterns, mainly by creating less formal situations which are less subject to established control mechanisms (Kwiatkowska 1978). "The analysis of artistic creations of various family members has made it possible to delineate the specific similarities in the styles of thinking and perceiving of parents and children" (Kwiatkowska 1967: 37). For this reason, some Family Art Therapy techniques, especially the "art therapy assessment of the family” (Hoshino 2008; Malchiodi 1998), are recognized as forms of clinical interviewing, not least because of their systematic and standardized procedures.

Following Karin Jordan (2001: 52), it can be assumed that Family Art Therapy "can be used as the sole family treatment technique, as a supplement to family treatment, or as an evaluation technique in family treatment." According to the chosen option, therapists can play different roles, activating family members to participate in new artistic experiences which:

- illustrate feelings, authenticity, awareness, spontaneity, and understanding;

- focus on the dynamic of family-of-origin and show clients the level of differentiation of the self;

- help understand family subsystems and boundaries;

- work as a tool for paradoxical intervention and problem resolution;

- show communication patterns (Sumari 2005).

In this way, therapists define the goals of Family Art Therapy, which sometimes vary because they result from different needs and problems of each family, as well as its individual members. However, synthetically the goals of Family Art Therapy were defined by Doris Banowsky Arrington (2008: 5) "Family art therapy goals are to provide time, materials, and a self-environment where therapeutic art procedures (spontaneous image-making, selecting of art media and materials, and when appropriate, verbal reflecting in response to questions specifically designed for this particular family or these individuals within their family and their culture) facilitate favorable 
personality changes and patterns. In such an environment, clients use the universal language of art and image for expression, in the process of relaxing, remembering, and recounting stressful or distressing experiences." Thus, on the one hand, art media and their various modalities are used to communicate, and to express oneself, but also to diagnose family problems, as a tool for coping with problems. On the other hand, the process of evaluating the family system, a way of intervening in its structure and history, discovering the transmitted patterns of behavior - all this complements each other to constitute Family Art Therapy, which, however, still has its own cultural differences contingent on the country, nationality, religion and tradition (Kerr 2015). And while this is not the place to discuss these cultural perspectives in detail, it should be borne in mind that the cultural diversity of family functioning and the diversity of culture, including the arts of a given cultural circle, are reflected in the unique experiences of working with families from different parts of the world. This not only makes Family Art Therapy more diverse, but is also a challenge for therapists.

\section{Family Art Therapy interventions}

In the source literature, it is not easy to find descriptions of art therapy interventions used in work with families who struggle with a specific clinical problem. This is probably because therapeutic work starts with a diagnosis of an individual case and only then introduces activities targeting the family into the process, if necessary/indicated. Therefore, some family interventions are not presented as Family Art Therapy but as activities focused on the treatment of selected disorders.

Available reports on art therapy activities with families focus on three main problems:

1. family functioning that is disturbed as a result of the health condition of one of its members; most often it is a child who experiences severe mental disorders, e.g. schizophrenia, mood disorders like depression, suicide attempts, etc. or ADHD, ASD and neurodevelopmental disorders;

2. the functioning of the family disturbed as a result of external conditions: crisis situation, and domestic violence; 
3. disorders in the relationship between one or both parents and the child.

The first group of problem cases has a classic nature, and was first described by Kwiatkowska (1967) with the characteristics of art therapy of a hysterical family. Descriptions of art therapy procedures are available in the literature (Kwiatkowska 1967, 1978, Nieduziak 2014, Malchiodi 2014). It is worth noting the six-stage structured and standardized evaluation procedure that started Family Art Therapy, carried out by the patient and his/her family individually and together during a 1 to 2 -hour session, with the observing participation of an art therapist and a psychiatrist or social worker involved in the psychotherapy of a specific family. After the evaluation, longterm or intermittent treatment was continued depending on family response and the overall treatment program. In some cases, determined by therapeutic motives or research goals, the patient suffering from schizophrenia could also pursue individual art therapy sessions (Kwiatkowska 1967).

Kwiatkowska (1967) emphasized the analytical and psychoanalytical nature of the program, focused on reducing the controlling role of the superego and on interpreting the symbols contained even in very primitive visual forms. The evaluation procedure contains two doodle-drawing tasks, which refers to one of the psychoanalytical techniques of therapy for children by Donald Woods Winnicott (1971). Kwiatkowska's program was aimed at adolescents suffering from schizophrenia or other forms of severe psychosis, hospitalized in psychiatric wards and for their families. As she herself pointed out, in her work she drew on a psychodynamic psychotherapeutic technique called "conjoint family therapy," in which the patient is perceived in the context of his/her relatives: the parents and siblings.

Fran Nielsen, Isabelle Feijo, Kate Renshall and Jean Starling (2021) addressed their program to a similar group of clients using the responsive family art psychotherapy described above in order to create situations that reveal hidden family dysfunctions and provide safe, non-verbal access to psychological content related to trauma. They also hypothesized that this type of intervention is recommended to support parents in identifying with the child's disease, improving their emotional relations with the child, and separating their child's disease symptoms and consent to their own therapy. 
The authors focused on the communicative aspect of art therapy, which allows clients to express feelings in a safe way and discover the relationship between thinking and emotions. The argument for the program was neurobiological research showing the connection between problems in verbal expression and language and changes in the activity of the amygdala and the left cerebral hemisphere caused by previous trauma (Klorer 2005). The authors also referred to older concepts of art therapy, including the recognition that early emotional relationships between a child and mother are reflected in joint artistic creation.

The main way of working was to visualize emotional experiences. "The final image is a record of the therapeutic interaction during the session or sessions over time and much of the process of communications and thinking together is held in the image.... The role of the art therapist within family art therapy is to create a safe, boundaried space within which both the child and their parent/carer can learn to recognize, understand, and regulate their own feelings. In addition, the images created provide opportunities for the parent to engage in guided reflection about their own emotional responses and develop an understanding of their child's behavior" (Nielsen, Feijo, Renshall, Starling 2021: 147).

Therapists presented three case studies of teenage psychiatric patients undergoing long-term treatment, with an average duration of two to three years of mental illness, often with multiple comorbidities (depression, suicide attempts, self-mutilations, using psychoactive substances, school absenteeism, PTSD, and psychotic disorders). The patients had previously undergone psychiatric treatment, including inpatient treatment: this time a multidisciplinary approach was proposed. Family therapy was part of the daily schedule in the ward, but as an art therapy, it was offered to those patients and families who were experiencing difficulties in building relationships. The meetings were held regularly three times a week for one hour each and, depending on the needs, took the form of short-term (three meetings) and more intensive sessions (twelve meetings). The parents and the child worked individually doing their visual artwork followed by a discussion if the patient felt the need to do so.

The sessions turned out to be beneficial for both a better mutual understanding between the parent and the child, especially in 
emotional terms, and for the work of parents. In particular, they also fulfilled diagnostic functions, revealing the emotional states of the parents, who are not under medical care but play an important role in the recovery of their children. In one case, the experience of individual art therapy sessions without the participation of the child helped the parent discover his own problems; in another, however, the parent's awareness of their own distressing emotional states did not motivate them to work on the change.

It is also worth paying attention to the modest artistic background of the sessions, in which the therapists limited themselves only to painting activities and using the simplest tools. Meanwhile, H.Y. Kwiatkowska (1978) and Judith A. Rubin (2005) encourage the use of large surfaces, e.g. for family portraits, where the participants can use two and three-dimensional media. The family murals in the J. Rubin technique take the form of an image painted on a large sheet of paper glued to the wall. According to the authors, the large possibilities of using any media reduce the stress level of the participants.

Diane S. Safran (2014) proposes a similar organization of activities in art therapy of families of children with ADHD, arguing that large artworks show the dynamics of family relationships and the reactions of individual people to joint ventures. Her experience in working with this therapy audience did not translate into the development of a particularly different procedure. However, when describing the case of several-year-old Bill and his family, she draws attention to both small manifestations of the child's creativity, e.g. drawings, which are an important source of information, and to joint family activities aimed at recognizing the emotions triggered by the behavior of a child with ADHD and developing coping strategies, as well as practicing assertiveness and relationship patterns that should not be dominated by the child. The main task of the art therapist in this case is to observe the behavior of family members when they are performing joint tasks (e.g. drawing an artwork depicting a joint trip or an island and arranging family life on it) and sharing conclusions and discussing them with parents.

Robin L. Gabriels and Lyndsay J. Gaffey (2014) propose a similar strategy, based primarily on the analysis of observation results in family art therapy in families with children with ASD. They propose a three-stage model of work, which consists of: 
1. an open-ended command/task, usually without a subject, title or execution method. It has a diagnostic function and is used to examine the role and position of individuals in the family and the ability of parents to control the behavior of their child with ASD. This part is usually very difficult for people with autism because they prefer clearly structured activities that indicate how to perform the task.

2. creating a structure for the activities by defining the rules of work, procedures for doing the activities, defining possible tools, methods, and ways of organizing the work, e.g. time, expected outcome;

3. an interview with the parent during which the behavior of the child and the cooperating family members are analyzed.

The presented examples of family art therapy interventions show that despite the similarity of problems, the methods of conducting art therapy sessions are different and result not only from different assumptions made by the practitioners, but also from the functioning of the family, which is determined by the features of the disease and disability. Family Art Therapy implemented with families with children with mental illnesses, especially adolescents, is based on the insight made by all participants. Meanwhile, in art therapy of families with children suffering from neurodevelopmental disorders, more emphasis is placed on the analysis of behaviors observed during classes rather than on the understanding of the content and meanings in the artworks.

The second group of interventions with the use of Family Art Therapy opens with the example of therapeutic work in the son-mother dyad. The starting point was the boy's behavioral problems after his father's death. A modest description by J. Rubin (2010) indicates the adoption of an interview-based model, which was used to diagnose the problem, observe the jointly performed task, a drawing, and to view and exchange the meanings in their own and the other person's works. More data can be found in the publication of H. Manicom and T. Boronska (2003), in which the authors emphasize the interdisciplinary nature of their project and, consequently, the adoption of therapeutic and educational goals in working with families in crisis. The initial diagnosis of that case study showed numerous problems in the entire family system, both in the children and the 
parents. The starting point was the referral to art therapy classes of a five-year-old girl who experienced physical abuse from her father, who was unable to cope with the stress of being unemployed. The father left the family, which averted the danger of him continuing his inappropriate behavior, but made the mother the only person responsible for the children. The children had symptoms of various problems, both emotional, e.g. nightmares, withdrawal, and cognitive manifested by learning difficulties at school, and social manifested by behavioral disorders, such as tantrums. In the complicated system of family relationships, the mother of the children felt under-resourced and insecure. While remaining under the care of social welfare, the family was offered joint art therapy classes. The basic artistic medium was drawing supplemented with play materials. The therapists used simple materials, focusing more on the subject of the work and not on exploring the artistic means of expression. Nevertheless, some of the works were not very directive, e.g. the topic of the first work concerned the image of the family; some were expressions of intuition and resulted from the children's communication needs. For example, a spontaneous drawing of an elephant initiated an exchange of animal pictures. The therapists, however, did not use the known diagnostic techniques using drawings, but used them as material to initiate conversations about family relationships or to reflect on their own family and family of origin. The narrative material consisted of the reconstruction of the family history, which influenced family members but also required them, especially the parents, to make an effort to change.

As can be seen in both of the above examples, the artworks were used as a material initiating communication within the family. The drawings proved to be not only a different form of communication, but they also facilitated access to unconscious content, especially feelings, and initiated the process of working through problems. As it turns out, it was not always necessary to explain and discuss the works created, as images can act on a symbolic level, especially when they are accompanied by strong emotions. One should also bear in mind the possible refusal to use artistic expression, which is common in adults and may be an expression of resistance to therapy.

The third group of Family Art Therapy interventions is illustrated by two examples of activities addressed to families in which the 
initial situation in therapy does not require deep intervention or such intervention is not urgent. The first one serves only to signal the possibility of using diagnostic techniques in Family Art Therapy (Nieduziak 2014). Even in light of the numerous definitions of art therapy, its task is not to make diagnoses: many art therapists use projection techniques or other diagnostic techniques, most often drawing, either for diagnosis or as inspiration for original art therapy activities. An example of such an intervention is the use of the Joint Family Holiday Drawing technique to improve family relationships and earlier to collect information about the family and observe them working together. K. Jordan (2001) describes a case of a family of four in which the parents noticed the first symptoms of disturbing behavior in their adolescent daughter. The mother reported to the counselor that their eldest daughter was becoming more and more provocative, especially towards her father. In an initial interview, she described the family as overall well-functioning and added that the eldest daughter had always been a "good child." The parents did not recall any events that could have caused the change in their daughter's behavior.

The counselor suggested a few meetings of the whole family and started working with the diagnostic technique mentioned above, proposing that they should create a drawing of one of their family holidays (e.g. Christmas, $4^{\text {th }}$ of July, birthday, etc.). The family was also asked to make the exercise non-verbal. Therefore, the basis for further work was the conclusions from the observation of the family and the product of joint activities submitted to family discussion. The technique applied was used to assess mutual family relationships, responsibilities and the division of roles, and it provided a clue about the family atmosphere.

The proposal of art therapy activities aimed at strengthening the bond between the parent and the child proposed by Pierre Plante and René Bermèche (2008) is much more complicated. Their project was constructed to test the effectiveness of art therapy, but it can also serve as an inspiration and even a role model for art therapists. The project was prepared with the intention of working in parent-child dyads, which is why the impact was on single parents with their children. The activities took the form of a series of nine workshops offered to families during evening meetings at the Center d'Assistance 
d'Enfants en Difficulté, in the time free from school and work. They consisted of the following activities:

1. doodling together;

2. work on the basis of body contours;

3. plaster casts of masks and hands;

4. handmade slides;

5. clay for the vision-impaired;

6. salt dough and family drawing;

7. cardboard and plaster constructions;

8. cardboard and plaster constructions-continuation;

9. cardboard and plaster constructions-continuation and circle drawing.

In addition to the variety of proposals, the couples were invited to joint or separate activities according to a prepared scheme. Apart from the first meeting, each subsequent meeting followed a regular schedule: the first part of the activities focused on the previous meeting, the second part on the creation process, and the third part was a short summary of the activity before leaving home. An important feature of the activities was their playful character, which did not aspire to gain insight, but aimed to strengthen the relationship between the parent and the child. In this regard, the authors referred to D. Winnicott (Wilson, Robinson 2002), already mentioned in the text; this time, by adopting the author's concepts of transitional space and transitional objects, which, in art therapists' views, are the spaces in which the act of creation and the resulting work takes place (Malchiodi 2014).

The participants appreciated the fact that the project created circumstances which encouraged creative freedom and open expression, both verbal and artistic, that were not subject to evaluation. They exhibited an attitude of calmness, which helped them experience the tasks more deeply and became an inspiring model experience, transferrable to relations beyond the dyad. Most of the participants noticed that from the beginning of the meetings, the leaders put emphasis on building trust.

In this group of art therapy interventions, the playful aspect of the proposed activities seems to prevail, even if their goal is to diagnose the family. The entertaining character of the sessions does not, however, exclude activities that provoke deep experiences and motivate 
to make changes. Sometimes it is a more effective way than activities labelled as therapeutic, the awareness of which may be a source of resistance in psychotherapy.

\section{Examples of art therapy works}

There is one more manifestation of Family Art Therapy that deserves attention, namely self-therapeutic work and supervision of art therapy practitioners. This usually takes place in the training of future art therapy adepts. As it is not always possible to offer a separate education path dedicated to family art therapy in the curricula, examples of students' self-therapeutic work are all the more valuable. The starting point for the artistic and therapeutic process was the preparation of a traditional genogram [Jolly, Froom, Rosen 1980] of one's own family, containing information about family members up to the third generation back. This task became an inspiration for family conversations and reconstructing the network of family ties, discovering family secrets and, in the further stages, analyzing family relationships while creating artistic works.

Example A (photo 1,2,3) shows an installation made of plastic baubles. The shape of the whole is a reflection of the family genogram. Inside the plastic balls, the author placed objects that are associated with particular people in her family. The colors of the threads with which the balls are connected correspond to the features of family relationships: from very good to broken.

Example B (photo 4) shows how a genogram can be combined with phototherapy [Weiser 2019] and reminiscence art therapy [Mahendran, Rawtaer, Fam, Wong, Kumar, Gandhi, Jing, Feng, Kua 2017] used in Family Art Therapy. While making the genogram, the author of the work discovered how much of her family consists of people who emigrated to the USA. She tried to recreate family relationships and stories, as well as explore the present. The visual (photographic) layer is made up of recovered family photos from the period 1970s-1990s. Each photograph is accompanied by a verbal commentary: a kind of bridge between the present and family history. While working on this material, the author of the exhibition also created a personal narrative. 
Example C (photo 5) shows an installation combined with photographs. It is a metaphorical conversation with the author's grandfather, who does not reveal his face. The viewer gets to know him only through the trophies of the family elder, who was a hunter. Working on the genogram motivated the author to talk to her grandfather and learn more about his biography. This work deserves special attention because of the deep symbolism of the skulls and antlers of dead animals. This sad metaphor of departing life is enhanced by the decoration of the antlers with colorful flowers. This is a somber symbol as the flowers have been dried.

\section{The value of Family Art Therapy}

In addition to the research and diagnostic value indicated above, and therapeutic value in itself, Family Art Therapy is also abundant material for therapists. Justifying the difficulties in choosing the case (family) and the artworks created during therapy, Kwiatkowska wrote: "Each piece of art work revived emotionally charged memories in the therapists which seemed as intense and vivid as during the session itself. Because this material carries the freshness of the original experience, it can be effectively reviewed with the family and is invaluable in working out distortion, denial, or resistance to therapy. It also enables therapists and families to see and follow the changes occurring during the course of therapy" (Kwiatkowska 1967: 37). 
Example A

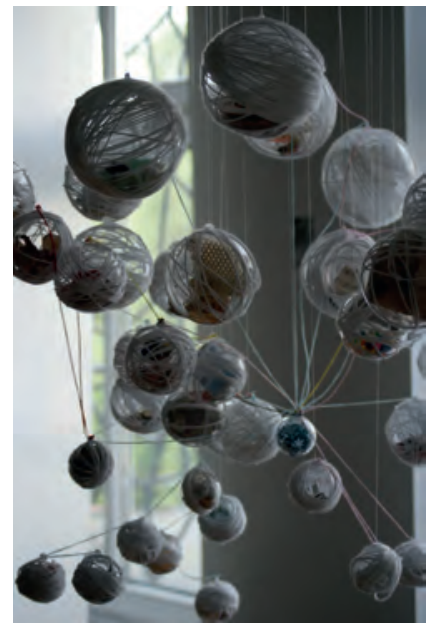

Photo 1

Example B

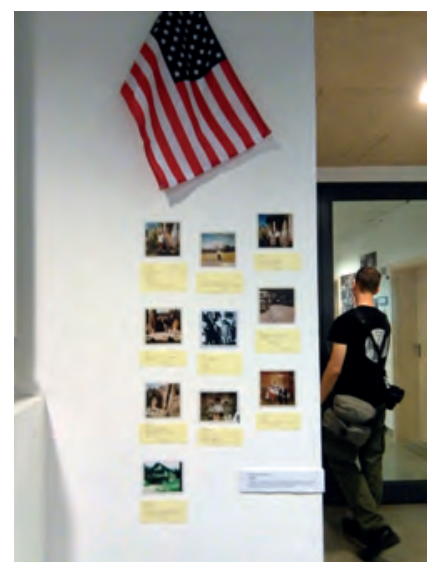

Photo 4

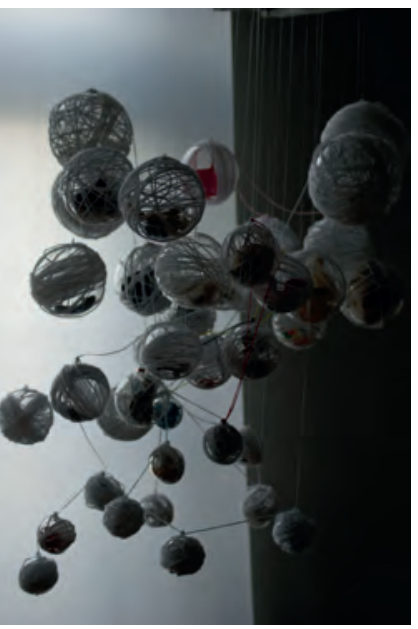

Photo 2

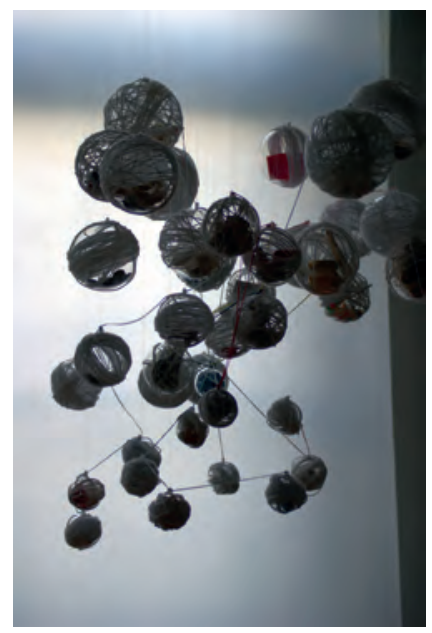

Photo 3

Example C

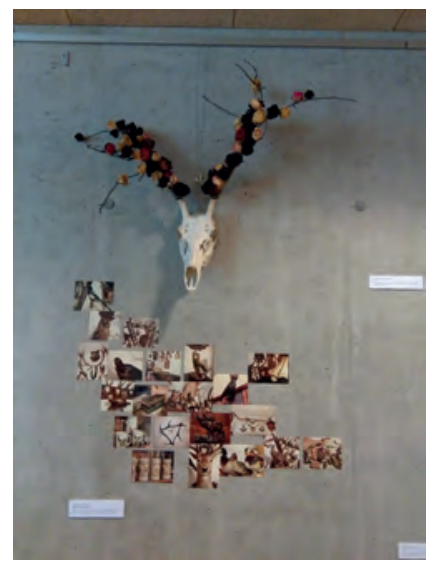

Photo 5 


\section{Bibliography}

Anderson F.G., Sweezy M., Schwartz R.C. (2020). Przerwodnik po terapii IFS: system wewnętrznej rodziny - praca z trauma, zaburzeniami lękowymi, depresja, PTSD i uzależnieniami, trans. A. Koluch-Horbowicz, Poznań: Dialogue Unlimited; Fundacja Miejsce Ludzi.

Arrington D.B. (2008). Home Is Where the Art Is: An Art Therapy Approach to Family Therapy, Springfield (IL): Charles C. Thomas.

Braverman L. (red.) (2003). Podstawy feministycznej terapii rodzin, trans. A. Tanalska-Dulęba, Gdańsk-Sopot: Gdańskie Wydawnictwo Psychologiczne.

Bybluk M. (2009). "Problemy rodziny i ich rozwiązywanie w świetle teorii i praktyki terapii rodzin," Rocznik Naukowy Kujawsko-Pomorskiej Szkoty Wyższej w Bydgoszczy. Transdyscyplinarne Studia o Kulturze (i) Edukacji, no. 4, pp. 47-60.

Chrząstowski S. (2014). Nie tylko schemat. Praktyka systemowej terapii rodzin, Warszawa: Wydawnictwo Paradygmat; Fundacja Altkom Akademia.

Coyne L.W., Murrell A.R. (2020). Radość rodzicielstwa. Jak odnaleźć równowagę, spokój i szczęście: terapia akceptacji i zaangażowania, trans. S. Pikiel, Sopot: Gdańskie Wydawnictwo Psychologiczne.

Dattilio F.M. (2013). Terapia poznawczo-behawioralna par i rodzin. Podręcznik dla klinicystów, trans. R. Andruszko, Kraków: Wydawnictwo Uniwersytetu Jagiellońskiego.

Dziewięcka-Bokun L. (2010). "Rodzina jako autoteliczna wartość polityki społecznej," Prace Naukowe Uniwersytetu Ekonomicznego we Wroctawiu, no. 146 , pp. 25-30.

Emanuel L., Bradley E. (eds.) (2018). Co się dzieje z tym dzieckiem? Interwencje psychoanalityczne w pracy z rodzinami z matymi dziećmi, trans. S. Grzymowicz, K. Pniewska, Warszawa: Oficyna Wydawnicza Fundament.

Encyclopedia of Psychotherapy (2002). M. Hersen, W. Sledge (eds.), vol. 1-2, Amsterdam: Elsevier Science.

Erickson M.H. (1997). Mój gtos podąży za tobą. Terapeutyczne przypowieści Miltona H. Ericksona, trans. B.K. Peczko, Poznań: Zysk i S-ka.

Frąckowiak M. (2007). "Rodzina jako wartość w świadomości współczesnych Polek,” Roczniki Socjologii Rodziny, vol. 18, pp. 15-38.

Gabriels R.L., Gaffey L.J. (2014). "Arteterapia dzieci ze spektrum autyzmu,” in C.A. Malchiodi (ed.), Arteterapia. Podręcznik, przeł. E. Bochenek, Gdańsk: Harmonia Universalis, pp. 246-263.

Górniak L., Józefik B. (eds.) (2003). Ewolucja myślenia systemowego w terapii rodzin. Od metafory cybernetycznej do dialogu i narracji, Kraków: Wydawnictwo Uniwersytetu Jagiellońskiego.

Haley J. (1995). Niezwykta terapia. Techniki terapeutyczne Miltona H. Ericksona, trans. M. Przylipiak, M. Majchrzak, Gdańsk: Gdańskie Wydawnictwo Psychologiczne. 
Hellinger B., Hovel T. (2003). Praca nad rodzina. Metoda Berta Hellingera, trans. A. Ubertowska, Gdańsk: Gdańskie Wydawnictwo Psychologiczne. Hoshino J. (2008). "Structural Family Art Therapy," in Ch. Kerr, J. Hoshino, J. Sutherland, S.T. Parashak, L.L. McCarley, Family Art Therapy: Foundations of Theory and Practice, New York-London: Routledge, pp. 118-150.

Hoshino J. (2016). Getting the Picture: Family Art Therapy, in D.E. Gussak, M.L. Rosla (eds.), The Wiley Handbook of Art Therapy, Chichester (UK)Malden (MA): Wiley Blackwell, pp. 210-220.

Hoshino J., Cameron C. (2008). "Narrative Art Therapy Within a Multicultural Framework," in Ch. Kerr, J. Hoshino, J. Sutherland, S.T. Parashak, L.L. McCarley, Family Art Therapy: Foundations of Theory and Practice, New York-London: Routledge, pp. 193-219.

Jolly W. Froom J., Rosen M.G. (1980). "The Genogram,: The Journal of Family Practice, vol. 10, no. 2, pp. 251-255.

Jordan K. (2001). "Family Art Therapy: The Joint Family Holiday Drawing," The Family Journal: Counseling and Therapy for Couples and Families, vol. 9, no. 1 , pp. 52-54.

Kerr Ch. (2008a). "Bowen Family System Theory and Family Art Therapy," in Ch. Kerr, J. Hoshino, J. Sutherland, S.T. Parashak, L.L. McCarley (2008). Family Art Therapy: Foundations of Theory and Practice, New YorkLondon: Routledge, pp. 95-117.

Kerr Ch. (2008b). "Experiential family therapy and art therapy," in Ch. Kerr, J. Hoshino, J. Sutherland, S.T. Parashak, L.L. McCarley, Family Art Therapy: Foundations of Theory and Practice, New York-London: Routledge, pp. 95-117.

Kerr Ch. (ed.) (2015). Multicultural Family Art Therapy, New York-London: Routledge.

Kerr Ch., Hoshino J., Sutherland J., Parashak S.T., McCarley L.L. (2008). Family Art Therapy: Foundations of Theory and Practice, New York-London: Routledge.

Klorer P.G. (2005). "Expressive Therapy with Severely Maltreated Children: Neuroscience Contribution," Art Therapy, vol. 22, no. 4, pp. 213-220.

Kuźnik S., Landwójtowicz Ł. (2019). Wsparcie dziecka i rodziny: podstawy terapii behawioralnej i systemowej, Opole: Redakcja Wydawnictw Wydziału Teologicznego UO.

Kwiatkowska H.Y. (1967). "Family Art Therapy," Family Process, vol. 6, no. 1, pp. 37-55.

Kwiatkowska H.Y. (1978). Family Therapy and Evaluation through Art, Springfield (IL): Charles C. Thomas.

Malchiodi C.A. (1998). Understanding Children's Drawing, New York: Guilford Press.

Malchiodi C.A. (2014). "Arteterapia rodzin i par," in C.A. Malchiodi (ed.), Arteterapia. Podrecznik, trans. E. Bochenek, Gdańsk: Harmonia Universalis, pp. 474-487. 
Manicom H., Boronska T. (2003). "Co-creating Change within a Child Protection System: Integrating Art Therapy with Family Therapy Practice,” Journal of Family Therapy, vol. 25, no. 3, pp. 217-232.

McCarley L.L. (2008). "Filial Art Therapy: A Rogerian Approach," in Ch. Kerr, J. Hoshino, J. Sutherland, S.T. Parashak, L.L. McCarley, Family Art Therapy: Foundations of Theory and Practice, New York-London: Routledge, pp. 180-192.

Minuchin S. (2018). Kunszt terapii rodzinnej, trans. A. Tanalska-Dulęba, Warszawa: Wydawnictwo Paradygmat, Fundacja Altkom Akademia.

Nieduziak E. (2014). "Zastosowanie arteterapii i terapii kreatywnych w pracy z dzieckiem i rodziną," in S. Badora, P. Maciaszczyk, M. Piątek (eds.), Pedagogika opiekuńcza wobec problemów rodziny i możliwości jej wspierania, Tarnobrzeg: Wydawnictwo Państwowej Wyższej Szkoły Zawodowej im. prof. Stanisława Tarnowskiego, pp. 238-257.

Nielsen F., Feijo I., Renshall K., Starling J. (2021). "Family Art Therapy: A Contribution to Mental Health Treatment in an Adolescent Inpatient Setting," Australian and New Zealand Journal of Family Therapy, vol. 42, no. 2, pp. $145-159$.

Parashak S.T. (2008). “Object Relation and Attachment Theory: Creativity of Mother and Child in the Single Parent Family," in Ch. Kerr, J. Hoshino, J. Sutherland, S.T. Parashak, L.L. McCarley, Family Art Therapy: Foundations of Theory and Practice, New York-London: Routledge, pp. 65-93.

Peseschkian N. (2015). Pozytywna terapia rodzin. Rodzina w roli terapeuty, trans. R. Ciesielski, Wrocław: Wydawnictwo Continuo.

Plante P., Bernèche R. (2008). "Élaboration et évaluation par l'approche phénomenologique d'un groupe d'art-thérapie s'adressant à des dyades et ayant pour objectif le renforcement du lien parent-enfant," Canadian Art Therapy Association Journal, vol. 21, no. 1, pp. 35-52.

Riley S. (1988). "Adolescence and Family Art Therapy: Treating the "Adolescent Family" with Family Art Therapy," Art Therapy, vol. 5, no. 2, pp. 43-51.

Riley S. (1991). "Couples Therapy/Art Therapy: Strategic Interventions and Family of Origin Work," Art Therapy, vol. 8, no. 2, pp. 4-9.

Riley S. Malchiodi C.A. (2004). Integrative Approaches to Family Art Therapy, Chicago (IL): Magnolia Street.

Rubin J.A. (2005). Child Art Therapy, Hoboken (NJ): John Wiley \& Sons.

Rubin J.A. (2010). Introduction to Art Therapy: Sources and Resources, New York: Routledge.

Safran D.S. (2014). “Arteterapia w leczeniu ADHD,” in C.A. Malchiodi (ed.), Arteterapia. Podręcznik, trans. E. Bochenek, Gdańsk: Harmonia Universalis, pp. 232-245.

Satir V. (2000a). Rodzina. Tu powstaje cztowiek, trans. E. Ochmańska, M. Trzebiatowska, Gdańsk: Gdańskie Wydawnictwo Psychologiczne. 
Satir V. (2000b). Terapia rodziny, trans. O. Waśkiewicz, Gdańsk: Gdańskie Wydawnictwo Psychologiczne.

Selekman M.D. (2010). Collaborative BriefTherapy with Children, New York: Guilford Press.

Sutherland J.H., et al. (2008). "Alderian Family Art Therapy, in Ch. Kerr, J. Hoshino, J. Sutherland, S.T. Parashak, L.L. McCarley, Family Art Therapy: Foundations of Theory and Practice, New York-London: Routledge, pp. 167-179.

Sutherland J. (2011). "Art Therapy with Families," The Journal of Individual Psychology, vol. 6, no. 3, pp. 292-304.

Swadźba U. (2012). Wartości - pracy, rodziny i religii - ciagtość $i$ zmiana. Socjologiczne studium spoteczności ślaskich, Katowice: Wydawnictwo Uniwersytetu Śląskiego.

Weiser J. (2019). PhotoTherapy Techniques: Exploring the Secrets of Personal Snapshots and Family Albums, London-New York: Routledge.

Wilson A., Robinson N.M.T. (2002). "Transitional Objects and Transitional Phenomena," in Encyclopedia of Psychotherapy, eds. M. Hersen, W. Sledge, vol. 2, Amsterdam: Elsevier Science, pp. 861-866.

Winnicott D.W.(1971).Playing and Reality, London:Tavistock Publications.

\section{Netography}

Mahendran R., Rawtaer I., Fam J., Wong J., Kumar A.P., Gandhi M., Jing K.X, Feng L., Kua E.H. (2017). "Art Therapy and Music Reminiscence Activity in the Prevention of Cognitive Decline: Study Protocol for a Randomized Controlled Trial," Trials, vol. 18, no. 324, pp. 1-10, https://www.ncbi.nlm.nih.gov/pmc/articles/PMC5508683/ [access: 31.07.2021].

Sumari M. (2005). "Integrating Art Therapy with Family Therapy," Masalah Pendidikan, vol. 28, no. 1, pp. 41-48, https://myjurnal.mohe.gov.my/ public/article-view.php?id=12065 [access: 25.07.2021].

\section{ADDRESS FOR CORRESPONDENCE}

\section{Edyta Nieduziak}

University of Silesia in Katowice

Institute of Pedagogy

e-mail: edyta.nieduziak@us.edu.pl 